\title{
Heat-related Mortality as an Indicator of Population Vulnerability in a Mid-sized Central European City (Novi Sad, Serbia, summer 2015)
}

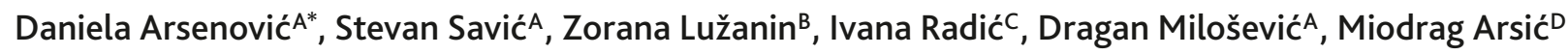 \\ Received: July 30, 2019 | Revised: December 16, 2019 | Accepted: December 19, 2019 \\ DOI: $10.5937 / g p 23-22680$
}

\begin{abstract}
Hot summers with several intensive heat waves lead to strong heat-related mortality in Central and Southeast European cities. Therefore, the aim of the study was to evaluate association between maximum temaprature and mortality during the summer period in 2015 and to contribute to the future long-term assessment of heat-related mortality in urban population. The daily number of deaths of all causes and cause-specific mortality for the population of Novi Sad were used, as well as hourly air temperature data from the Novi Sad urban network (NSUNET) system. Four heat waves were detected using the Huth and Kysely methods. Three heat wave periods lasted longer than ten days. In July and August, $45 \%$ of days had a maximum temperature above $30 \stackrel{\circ}{ } \mathrm{C}$, and more than $70 \%$ of days had a maximum temperature above $25 \circ \mathrm{C}$. The average number of deaths was higher during the heat wave days. Significant association was found between Tmax and all-cause, cardiorespiratory, non-cardiorespiratory in total population, all-cause and cardiorespiratory mortality in the age group 65 and over. This study demonstrates a high magnitude of relation between mortality and temperature. Finally, the results show that population in urban areas is highly vulnerable during heat waves.
\end{abstract}

Keywords: Mortality; heat waves; high temperature; urban population; Serbia

\section{Introduction}

It is widely recognized that extreme climatic conditions during summer months may constitute a major public health threat (Conti et al., 2005), can influence outdoor thermal conditions (Lehnert et al. 2018, Ongoma et al. 2016), mortality (Arsenović et al. 2019) and increase risk from heat hazards, particularly in urban areas. The association between mortality and various meteorological conditions has been studied across many scientific disciplines (Basu \& Samet, 2002), such as medicine, ecology, demography and various disciplines of geogprahy. During the $2 \mathrm{O}^{\text {th }}$ century, global climate changes sparked research about the influence of climate on mortality and most frequently, the major issue of interest was air pollutionand air temperature-related mortality (Kinney et al., 2008). The seasonality of mortality has been of interest for a long time and it has been associated with the effects of both heat and cold spells (Yi \& Chan, 2015; McMichael et al., 2008; Pattenden et al., 2003). Usually J-, V-, or U-shaped association has been detect-

\footnotetext{
A University of Novi Sad, Faculty of Sciences, Climatology and Hydrology Research Centre

B University of Novi Sad, Faculty of Sciences, Center for Mathematical Research of Nonlinear Phenomena

C University of Novi Sad, Faculty of Medicine

D Institute of Publich Health of Vojvodina

* Corresponding author: Daniela Arsenović, e-mail: daniela arsenovic@dgt.uns.ac.rs
} 
ed in cases of increased mortality due to cold and hot temperatures and the minimum mortality occurring at various points, depending on latitude (Analitis et al., 2008). There is no universal definition of a heat wave, but it is well documented that extreme events, particularly those associated with hot temperatures lead to notable impact on human mortality (Koppe et al., 2004; Meehl \& Tebaldi, 2004). Two most pronounced heat hazards are the Chicago heatwave in 1995 and 2003 heatwave in Paris (Klinenberg, 2015; Keller, 2015). In July 1995 Chicago was affected with strong heat wave (Klinenberg, 2015) which had harvesting impact on population and substantial effect on all-cause and specific-cause mortality. During 5 days this heat hazard took between 500 and 600 victims (Klinenberg, 2015; Jedlovec et al., 2017) and according to Klinenberg (2015) the risk of death during the heat wave, in all age groups, was higher among African Americans, and compared between gender, men were more vulnerable group then women. In the summer of 2003, much of Europe was affected by a very intensive heat wave, especially France, Germany, Italy, Switzerland and Portugal (Stott et al., 2004; Black et al., 2004). Despite claiming an estimated 70,000 lost lives all around Europe (Keller, 2015), France was the European country most affected by the heat wave with an estimated excess mortality of 54\% (Le Tertre et al., 2006). Intense heat disaster of summer 2003 in France caused about 15,000 victims (Keller, 2015). Human mortality is used as an indicator of human health in general (in medical studies) but also as indicator of vulnerability (in environmental studies) and in most of them a strong increase of mortality during heat waves is found (Kinney et al., 2008; Muthers et al., 2010). A similar to France, devastated effect was recorded in Italy, particularly among the elderly, especially people aged 75 and older (Conti et al., 2005). Baccini et al. (2008) studied heat effects on mortality in 15 European cities, indicating that the relationship between the maximum apparent temperature and log mortality rate was V- or J-shaped for most cities. Similarly, record-breaking temperatures were recorded in the summer of 2010 in Eastern Europe, particularly during July and August in central-western Russia (Barriopedro et al., 2011). The results presented by Barriopedro et al. (2011) show that events registered in summer 2010 had even more adverse effects than those in 2003 .
During the summer of 2003, Serbia was less affected by heat waves than other countries, while in 2007 , as well as in 2015, heat events resulted in a harvesting effect in major urban centres. The studies related with urban heat island effects suggest strong evidences that due to the heat island effect, population in cities is more vulnerable than in rural areas. Recent research (Gasparrini et al., 2015) suggests that air temperature is an important risk factor. Furthermore, studies related to the influence of summer heat waves on population reveal an increasing trend in cardiovascular mortality (McMichael et al., 2006; Cheng \& $\mathrm{Su}, 2010)$. Evidence about heat waves during summer months is important for population health, particularly concerning the urban heat island effect, which elevates heat stress several hours after sunset (Matzarakis et al., 2009). According to our findings, heat waves and their impact on mortality and public health in Serbia have so far been investigated for the long period (Djurdjev et al., 2012), and for the summer of 2007 (Stanojević et al., 2014; Bogdanović et al., 2013), for the urban area of Belgrade, the capital city of Serbia.

Dousset et al. (2011) have observed an increased frequency, intensity and duration of heat waves around Europe during the past decades. The Fifth Assessment of International Panel for Climate Change Report (2013) has shown that the increase in the maximum temperature and the number of hot days in the past decades are part of a global trend, which will probably lead to more frequent and intense heat waves in the future. According to studies dealing with heat wave events, the summer of 2015 was characterized by a record-high heat intensity in Central and Eastern Europe (Hoy et al., 2017; Lhotka et al., 2017), as shown by the studies of Russo et al. (2015) and Dong et al. (2016), who categorized 2015 heat events among the most severe since 1950.

In order to strengthen and improve the understanding of the associated health effects of heat waves, further evidence is needed. Accordingly, this study presents the results of daily temperature-related mortality in the urban population of Novi Sad (Serbia) in the summer of 2015. The aim of the study, focusing on the restricted summer period (June-August), was to evaluate association between maximum temperature and mortality, and to contribute to: (1) beter understanding heat hazards as health risk; (2) future longterm assessment of heat-related mortality in urban population and help mitigate the current trend. 


\section{Materials and methodology}

\section{Study area}

Novi Sad is the second largest city in Serbia and it is located in the northern part of the country (Fig. 1). With a built-up area of $102 \mathrm{~km}^{2}$ Novi Sad is located in a plain between 76 and $80 \mathrm{~m}$ a.s.l (Savić et al., 2016). The Novi Sad City (Novi Sad and smaller settlements in its vicinity) had about 380,000 inhabitants in 2015, according to the population register. The urban area of Novi Sad (investigated in this study) had approximately 300,000 inhabitants (Fig. 2).

The southern part of Novi Sad is situated on the northern slopes of the low mountain of Fruška Gora, while the Danube River flows through the southern and southeastern edges of the city (Savić et al., 2013). Using the Köppen-Geiger classification system (Kottek et al., 2006), the Novi Sad region is classified in the $\mathrm{Cfb}$ climate category with a temperate warm climate and fully humid and warm summers. The mean monthly temperature varies from $-0.4^{\circ} \mathrm{C}$ in January to $21.7^{\circ} \mathrm{C}$ in July (Savić et al., 2016). From the 2003 in Serbia, as well as in the whole Europe, the heat waves start to appear more frequently, mostly during the summers. One of the most intensive heat wave above Novi Sad appears during the July 2007, with apsolute maximum temperature of $41.6^{\circ} \mathrm{C}$. After that, particularly in years 2012, 2015, 2017 the multile number of intensive heat wave appear in Novi Sad. The downtown

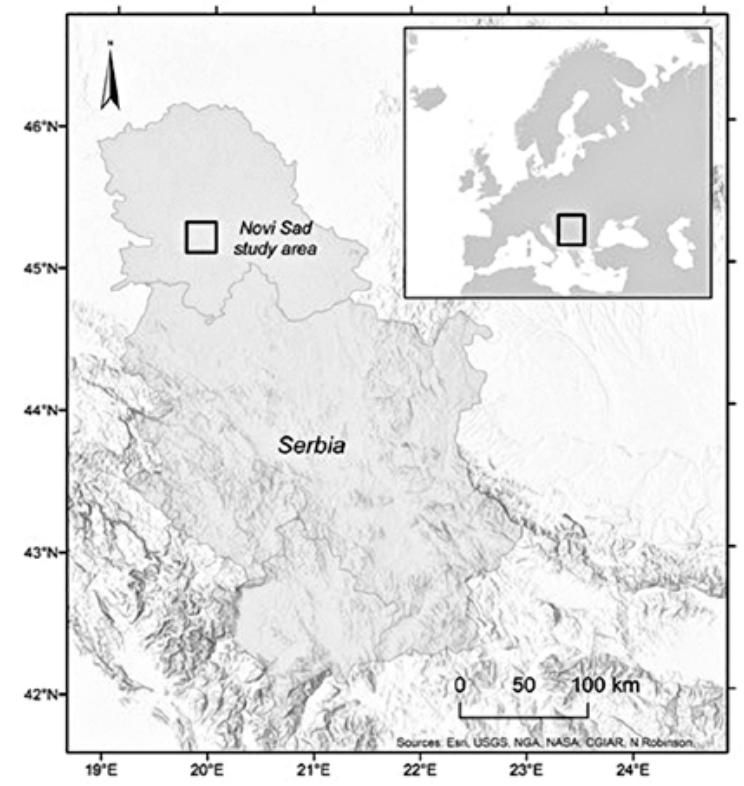

Figure 1. Location of Novi Sad urban area in Serbia and Europe

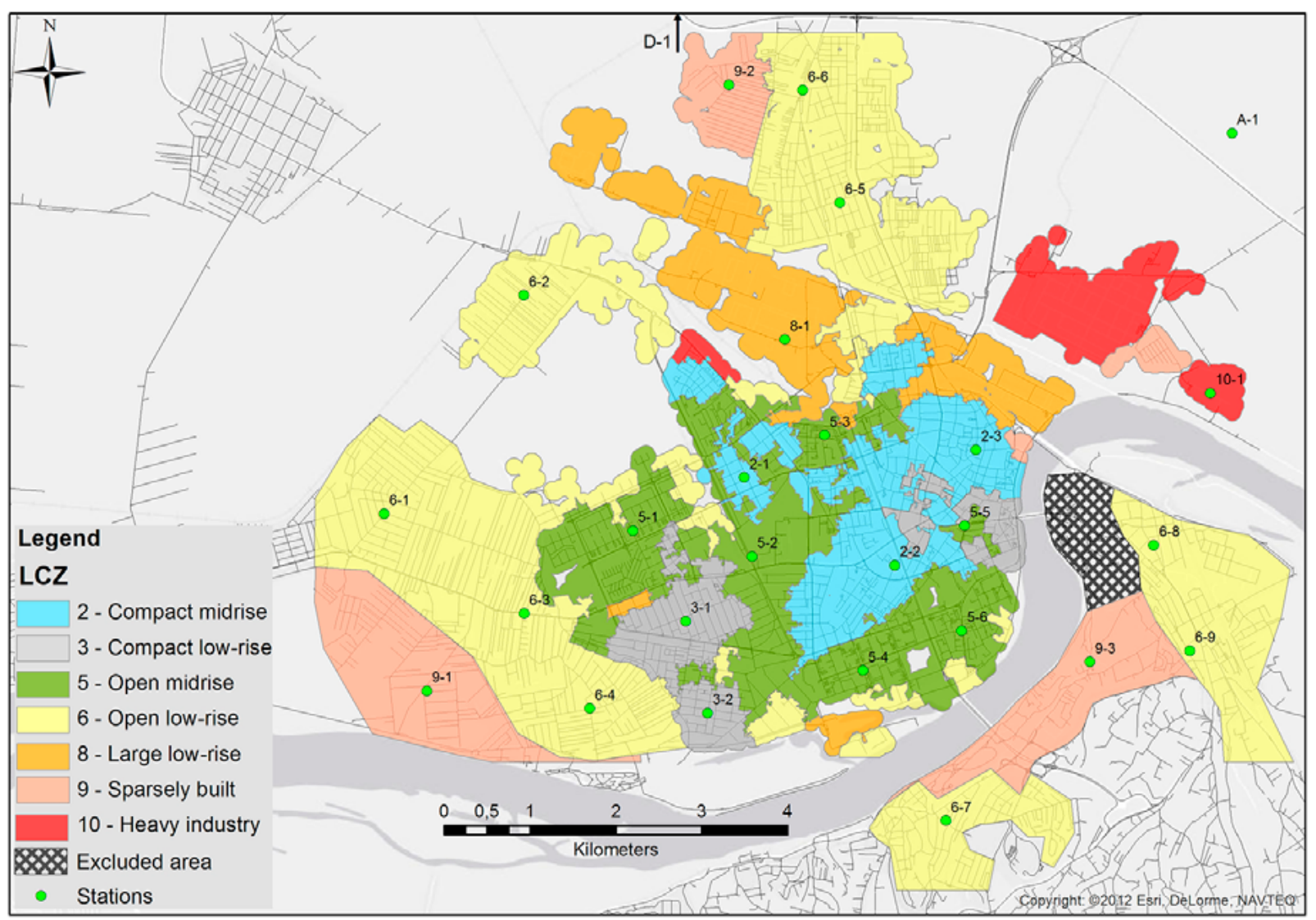

Figure 2. Urban area of Novi Sad with 25 used measurement stations and delineated different urbanization tipes/ Local Climate Zones based on Stewart \& Oke (2012) classification system 
area is densely built with mid-rise building blocks, while low-rise residential buildings prevail in suburban areas. Warehousing and industrial zones are located in the northern part of the city (Savić et al., 2013).

\section{Mortality data}

The daily counts of deaths for Novi Sad's urban area were taken from the database of the Institute for Public Health of the Vojvodina Province and were analyzed for all causes and cause-specific mortality due to circulatory and respiratory diseases. In circulatory causes of death, the following major categories were particularly considered: hypertensive diseases, ischaemic hearth diseases, cerebrovascular diseases and other forms of heart diseases. In the population of Novi Sad, respiratory diseases had small counts but they were very important causes of work (NSUNET) system. $T_{a}$ values for the summer of 2015 were obtained as averaged hourly data from 25 measurement stations located in the urban area of Novi Sad (Fig. 2). Stations had fully calibrated temperature sensors with an accuracy of $\pm 0.3{ }^{\circ} \mathrm{C}$ manufactured by the General Electric Measurement \& Control Company (Šećerov et al., 2015). Hourly $\mathrm{T}_{\mathrm{a}}$ was used in the analysis. The time of the measurement was converted to the local standard time in Novi Sad (i.e. Central European Time - CET). The final Ta database contained 55200 measurements. Since there was only a small amount of missing data (0.1\%), there was no significant bias in the final results.

In the further analysis, the focus was on the days with extreme Ta values. Accordingly, the methodology that showed good results in defining heat wave days in

Table 1. Number of deaths for the total population and the population aged 65 and over by causes of death, ICD-10 codes

\begin{tabular}{|l|c|c|c|}
\hline Cause of death & ICD-10 & $\begin{array}{c}\text { Total number of } \\
\text { death }\end{array}$ & $\begin{array}{c}\text { Number of death in } \\
\text { population } 65 \text { and over }\end{array}$ \\
\hline All causes & & 559 & 453 \\
\hline Diseases of the circulatory system & $100-199$ & 273 & 246 \\
\hline Hypertensive diseases & $110-115$ & 75 & 70 \\
\hline Ischaemic hearth diseases & $120-125$ & 58 & 50 \\
\hline Other forms of heart disease & $130-152$ & 93 & 83 \\
\hline Cerebrovascular diseases & $160-169$ & 40 & 37 \\
\hline All other diseases of circulatory system & $100-102,105-109$, & 7 & 6 \\
\hline Diseases of respiratory system & I26-I29, I70-179, 180-189 & 33 & 28 \\
\hline Neoplasms & C00-D48 & 148 & 100 \\
\hline All other causes & - & 105 & 79 \\
\hline
\end{tabular}

death when accompanied with temperature oscillation. In this paper, they were analyzed along with the major categories of circulatory mortality (as cardiorespiratory - CVD+R). The mortality data was classified according to the International Statistical Classification of Diseases and Related Health Problems (10 ${ }^{\text {th }}$ Revision).

The analysis was carried out for the total population, as well as for the old population (65 and over), as one of the most vulnerable group. The evaluation of heat-related mortality by gender was excluded due to the small population sample and the limited period.

During the three summer months of 2015, 565 deaths were recorded in the urban area of Novi Sad. Six cases were excluded from the analysis, due to incomplete data, and the final analysis was performed on 559 deaths. Only the permanent residents of the city who died in Novi Sad were included in the analysis.

\section{Climate data}

The high spatiotemporal resolution of temperature data $\left(T_{a}\right)$ was obtained from the Novi Sad urban net- other Central European cities (Huth et al., 2000; Kysely, 2002; Hutter et al., 2007) was also used in our study. The criteria defined the heat wave as a continuous period during which: a) daily maximum temperature $\left(\mathrm{T}_{\max }\right)$ reached at least $30{ }^{\circ} \mathrm{C}$ in at least three days, b) mean $\mathrm{T}_{\max }$ over the whole period reached at least $30^{\circ} \mathrm{C}$ and c) $\mathrm{T}_{\max }$ was not lower than $25^{\circ} \mathrm{C}$ (Huth et al., 2000; Kysely, 2002).

\section{Methods}

To eliminate the random variability effect from the number of deaths, as well as the influence of errors due to the time of death reporting, the 3-day accumulated mortality was used. Crude death rate is one of the most common use for mortality research, which represent the number of recorded death per 1,00o mid-year total population. Still, in daily investigation of number of death, main limitation is account for total number of population, due to the fact that number of inhabitants are available as mid-year population. In order to eliminate errors in results, measures are conducted using 
crude numbers. The number of deaths within 3-day period was examined as a dependent variable. As the data used belonged to the 2015 summer period, it was not possible to eliminate seasonal variability. Daily variability was not observed. Standard tests were conducted to compare the means of the 3 -day mortality from the groups of heat wave days and other days, as well as the groups based on age (65 and over) and cause of death. Regression analysis was applied to determine the dependence of the number of deaths on temperature, and the strength of the influence of daily temperature increase on the rise in mortality within particular groups.

\section{Results}

\section{Maximum temperature analysis} and determining heat wave days

According to $T_{a}$ measurements, the summer of 2015 was characterized by very intensive heat wave periods. Fig. 3 shows the average daily $\mathrm{T}_{\max }$ during the whole summer period in 2015. The results presented in Fig. 3 were obtained by average calculations using daily maximum values from all 25 stations located in the
Table 2. Number of continuous heat wave days in the summer of 2015 (according to the defined criteria by Huth et al., 2000 and Kysely, 2002)

\begin{tabular}{|l|c|c|c|c|}
\hline Date & June $4^{\text {th }}$ & July $4^{\text {th }}$ & July $17^{\text {th }}$ & ${\text { August } 6^{\text {th }}}^{\text {Heat wave }}$ \\
days & 13 & 4 & 4 & 14 \\
\hline
\end{tabular}

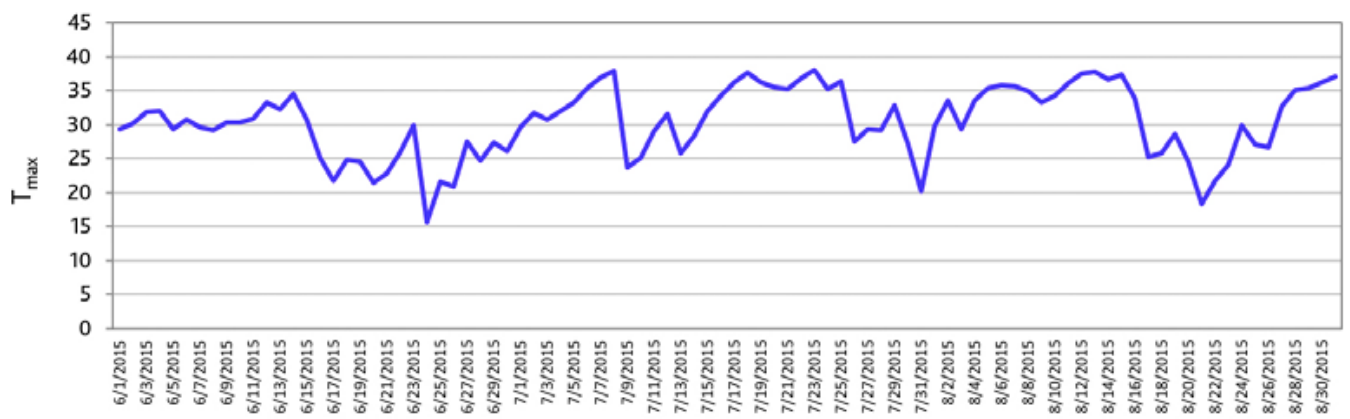

Days

Figure 3. Average daily $T_{\max }$ for the summer of 2015 in Novi Sad's urban area

urban area of Novi Sad. The curve shows four intensive heat wave periods that meet the defined criteria. The first heat wave period started on June $4^{\text {th }}$ with the average $\mathrm{T}_{\max }$ of $31.9^{\circ} \mathrm{C}$ and lasted for more than ten days. On July $4^{\text {th }}$ (average $\mathrm{T}_{\max }$ of $31.8^{\circ} \mathrm{C}$ ) started the second heat wave period that lasted 4 days, while on July $17^{\text {th }}$ started a 14 -day intensive heat wave period with an average $\mathrm{T}_{\max }$ ranging from $27.0^{\circ} \mathrm{C}$ (July $30^{\text {th }}$ ) and $37.9^{\circ} \mathrm{C}$ (July $23^{\text {th }}$ ). The last intensive heat wave occurred between August $6^{\text {th }}$ and August $19^{\text {th }}$ with an average $\mathrm{T}_{\max }$ between $25.1^{\circ} \mathrm{C}$ (August $17^{\text {th }}$ ) and $37.6^{\circ} \mathrm{C}$ (August $13^{\text {th }}$ ) (Fig. 3; Table 2).

The contribution of $\mathrm{T}_{\max }$ days in July and August with more than $30.0{ }^{\circ} \mathrm{C}$ was $45.2 \%$, while in June it was $20.0 \%$ (Fig. $4 \mathrm{a}$ ). The reasons were very intensive heat wave periods in July and August that lasted longer than ten days. A long heat wave period (13 days) was registered in June; yet, it was less intensive than the other two months. A similar situation is shown in Fig. $4 \mathrm{~b}$ with the contribution of $\mathrm{T}_{\max }$ days with more than $25.0{ }^{\circ} \mathrm{C}$. The maximum value was recorded in July, with $87.1 \%$, followed by August with $74.2 \%$ and June with $46.6 \%$ of $\mathrm{T}_{\max }$ days with more than $25.0^{\circ} \mathrm{C}$.
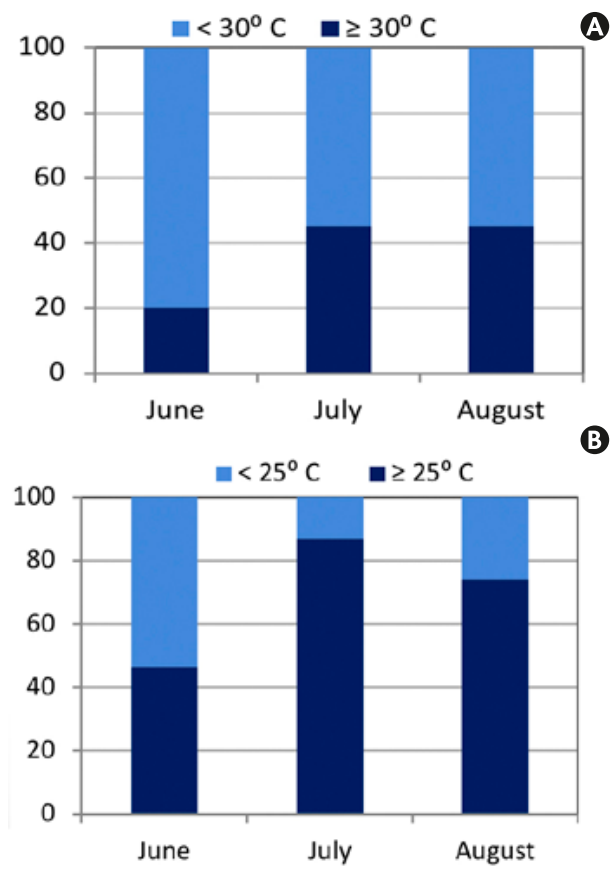

Figure 4. Days (in \%) with $\mathrm{T}_{\max }$

A) above/below $30^{\circ} \mathrm{C}$ and B) above/below $25^{\circ} \mathrm{C}$ for the summer of 2015 in Novi Sad's urban area 


\section{Temperature-related mortality}

The analysis of mortality fluctuations due to temperature changes was performed using $\mathrm{T}_{\max }$, all-cause and specific-cause mortality accumulated in $72 \mathrm{~h}(3$ days). The average daily number of deaths in three months period was about 6 . However, it may be observed in Table 3 that the average mortality was higher during the heat wave days. The intensity of heat-related mortality effects depended on the cause of death and age group. Fig. 5 reveals that higher $\mathrm{T}_{\max }$ values were followed by increased mortality counts and significant levels were registered for all-cause mortali- ty $(b=0.309518 ; r=0.3466, p=0.0008)$, cardiorespiratory mortality $(\mathrm{b}=0.173888 ; \mathrm{r}=0.2474, \mathrm{p}=0.0187)$ and non-cardiorespiratory mortality $(b=0.13563 ; \mathrm{r}=0.2572$, $\mathrm{p}=0.0144)$.

The old population (65 and over) contributed with more than $80 \%$ to the total mortality counts. Due to this, separate analyses for this age group were carried out. A positive, significant temperature-mortality association was found for the old population $(b=0.23332 ; r=0.2897, p=0.0056)$, particularly for those who died from cardiovasculary or respiratory disease. The association between cardiorespirato-

Table 3. Average number of deaths (3-day accumulated mortality) during heat wave days and in other days

\begin{tabular}{|l|c|c|c|}
\hline & Heat wave days (SD)* & Other days (SD) & P \\
\hline All-cause mortality & $19.997(3.772)$ & $17.000(4.585)$ & 0.0025 \\
\hline CVD+R mortality & $11.156(2.841)$ & $8.911(3.791)$ & 0.0046 \\
\hline Non-CVD+R mortality & $8.813(2.596)$ & $8.089(2.692)$ & 0.2228 \\
\hline All-cause mortality $(\geq 65+)$ & $15.844(3.342)$ & $13.554(4.058)$ & 0.0082 \\
\hline CVD+R mortality $(\geq 65+)$ & $10.219(2.733)$ & $7.661(3.538)$ & 0.5871 \\
\hline Non-CVD+R mortality $(\geq 65+)$ & $5.625(2.012)$ & $5.893(2.325)$ & \\
\hline
\end{tabular}
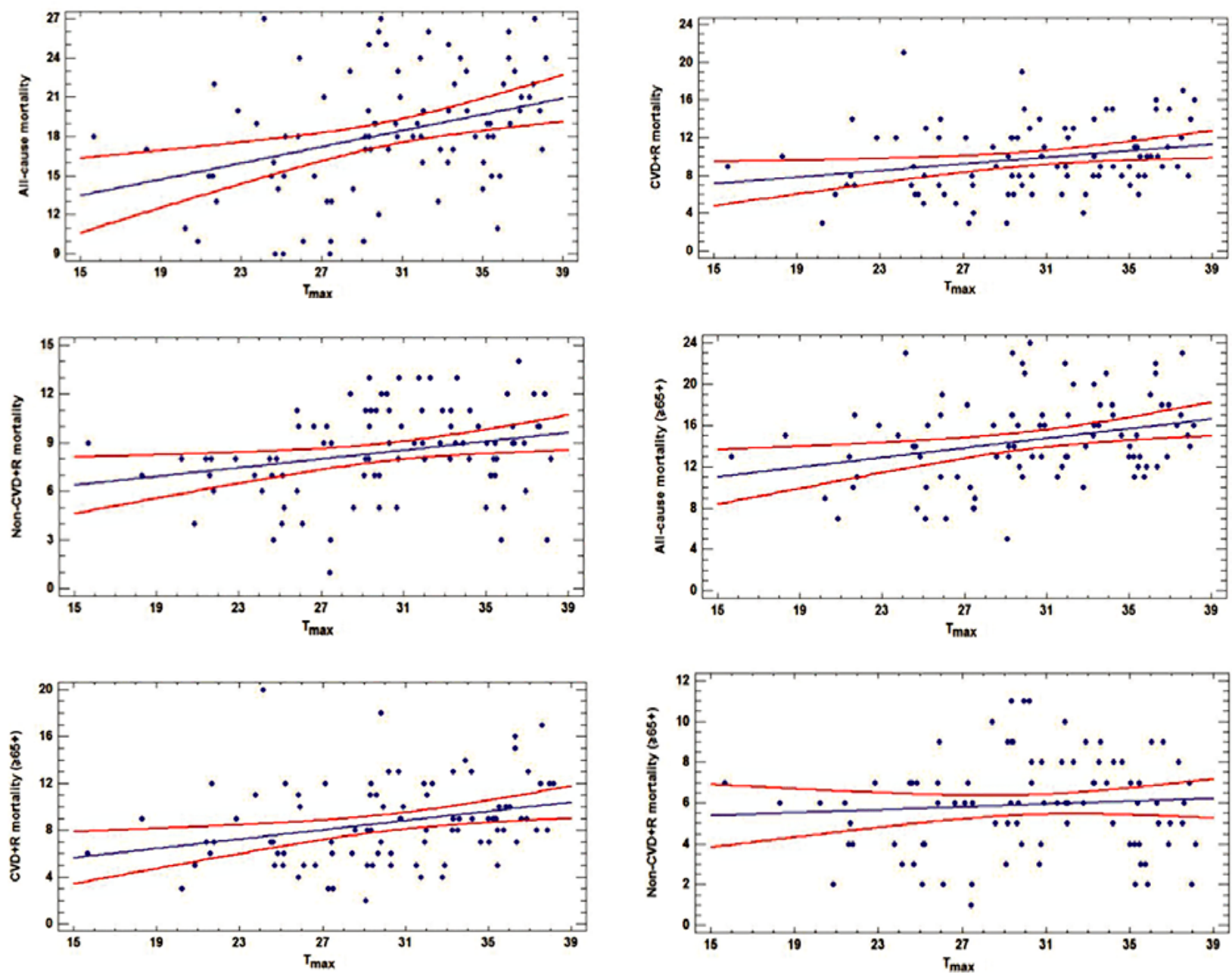

Figure 5. Association between accumulated 3-day mortality with $\mathrm{T}_{\max }$ (maximum temperature in ${ }^{\circ} \mathrm{C}$ ) for the summer of 2015 in Novi Sad. The blue line represents the fitted linear regression, while the red lines illustrate the confidence interval (with 95\%) 
ry mortality in the old population and temperature was also statistically significant $(b=0.19794 ; r=0.2912$, $\mathrm{p}=0.0054$ ), while no statistically significant asso- ciation was found between temperature and noncardiorespiratory mortality in the old population $(b=0.0353835 ; r=0.0784, p=0.4624)$.

\section{Discussion}

The increase in mortality during heat waves and a significant relation between $\mathrm{T}_{\max }$ and mortality in all population and population aged 65 and over in Novi Sad was observed. The results suggest that population in cities is the most vulnerable during heat wave events (McMichael et al., 2006; Matzarakis et al., 2009) and they compare well with the results from other European (Miron et al., 2015; Matzarakis et al., 2011; Michelozzi et al., 2006; Kysely, 2004) and non-European (Tong et al., 2014; Bustinza et al., 2013; Medina-Ramon \& Schwaertz, 2007) studies dealing with temperature-mortality issues. Therefore, heat waves have raised a growing interest in the research of climate change, urban environment, sustainable urbanization plans, public health and heat-related population fatalities (Hatvani-Kovacs et al., 2016).

The highest correlation with temperature was detected in all-cause mortality, then all-cause mortality of the population aged 65 and over, and cardiorespiratory mortality in the old population. It is well known that temperature changes and heat events are shaping the patterns of cardiorespiratory mortality. In the early 1990 s, a study conducted by Kalkstein (1993) showed that deaths directly related to heat could occur as a result of cardiovascular, cerebrovascular or respiratory breakdowns. Similar findings were presented in other studies reporting heat-related cardiorespiratory mortality (Lubczynska et al., 2015; Goldberg et al., 2011; Basu et al., 2005). Extreme temperatures could play an important role as a trigger for cardiovascular events due to changes in blood pressure, blood cholesterol or heart rate (Sun, 2010; Wolf et al., 2009).

In Novi Sad, more than half of all-cause mortality occurred in the old population with leading causes of death being cardiorespiratory diseases (about $60 \%$ ). About $90 \%$ of the total cardiorespiratory mortality counts were contributed by the old population. These results suggest that heat-related mortality in the old population significantly drive a shift of heatrelated all-cause mortality. Our findings are in line with other studies, suggesting that the old population is one of the most vulnerable groups affected by heat events and other temperature oscillations and extremes (Gabriel \& Endlicher, 2011; Schwartz, 2005; Diaz et al., 2002). The entire population is at health risk caused by heat waves, though studies suggest a higher risk among elderly people, socially isolated ones, those living alone, with no working air condi- tioning and those in top-floor appartments (Kovats \& Kristie, 2006).

No association was found between temperature and non-cardiorespiratory mortality in the old population due to the fact that neoplasms (Coo-D48) were the most frequent diseases in this category (about $56 \%$ ) and that these diseases were less affected by heat events. Moreover, recent research suggests that there is no association between the amplitude of cancer mortality and the latitude, implying that different environmental factors, e.g. temperature, do not influence cancer mortality (Marti-Soler et al., 2014).

While victims of heat events in Chicago (1995) and Paris (2003) were mostly characterized as poorest and most isolated population, abandoned and unnoticed by their neighbors (Klinenberg, 2015; Keller, 2015), inhabitants who died during the 2015 heatwave in Novi Sad were citizens lived in most urbanized areas with easy access to emergency services and health care. Majority of population in Serbia hold health insurance, for all permanent residents without health insurance, according to Serbian legislations, health insurance is covered by state budget. Concerning to this, as two key factors inducing heat hazards in cities could be identified: land use in the urban environment and local demographic (Jedlovec et al., 2017).

During the past two decades, Novi Sad has been exposed to intensive urbanization. From a demographic point of view, it is characterized by a progressive process of population ageing. The median age in Novi Sad is about 40 years (in 2011), and the share of the old population (65 and over) is about $14.2 \%$, while the percentage of the young population (o-14) is $14.8 \%$. As a consequence of fertility decline and an increased life expectancy, the share of the old population is expected to rise up to $28 \%$ by the mid-21st century. Moreover, due to an increasing life expectancy, the oldestold population (8o years and over) is a fast-growing age group. According to the data provided by the Statistical Office of Serbia, at the national level, the population aged 80 and over will be more than doubled by the mid-21st century. The demographic profile of the oldest-old population in Novi Sad is similar to the corresponding national demographic profile. In 2011, the share of the oldest-old population in Novi Sad was about $2.8 \%$. Until the middle of this century, it is expected to rise up to $7.8 \%$ (Arsenović \& Đurđev, 2012). More than one-half of people who died in Novi Sad in 
the summer of 2015 were aged 65 and over and half of them belonged to the 80 and over age group. Novi Sad is a medium-sized city with a high population density (520 inhabitants per square kilometre) and the majority inhabitants live in highly built-up urban neighbourhoods, with little or no green areas. According to the 2011 Census, the number of households with one member was about $30 \%$. People who live alone are marked as more vulnerable to heat-related mortality (Fouillet et al., 2006). Hence, with urbanization and an increasingly old population, heat-related mortality could be expected to become more severe.

Temperature impact on mortality was investigated in significant number of studies and papers and as indices for provement relation between temperature and mortality were used various parameters. The most common indicators of environmental hazard are minimum, maximum and mean temperature (Lubczynska et al., 2015; Stanojević et al., 2014; Bobb, Peng, Bell, \& Dominici, 2014; Bogdanović et al., 2013; McMichael, et al., 2008; Hutter et al., 2007; Fouillet et al., 2006; Kysely, 2004), relative humidity (Stanojević et al., 2014; McMichael et al., 2008), precipitation (McMichael et al., 2008) and human biometeorological indices, such as Physiological Equivalent Temperature (PET) index (Matzarakis et al., 2011). While for population vulnerability most often was used daily number of death by age and cause of death (Lubczynska et al., 2015; McMichael et al., 2008; Fouillet et al., 2006; Kysely, 2004), but also excess death (Stanojević et al., 2014; Bogdanović et al., 2013) and gender (Hutter et al., 2007). Despite a diverse number of indices, comparing result in this study with other, it can be pointed that results for Novi Sad are well fitted in recent finding, giving evidence that heat waves are important heat hazard leading to higher mortality during the days with extremely high temperature.

All previous analyses highlight the need for early warning systems and urgent human heat adaptation to mitigate the health efects of extreme temperature events. Since the 1960s, heat-related mortality risk has declined over time due to permanent adaptation and changes in vulnerability (Arsenović 2019; Arsenović 2018; Bobb et al., 2014; Donaldson, Keatinge, \& Nayha, 2003), but the risks of emergency hospitalization and mortality during heat waves are still high. Furthermore, climate change scenarios suggest an increase in the intensity of heat waves, which could lead to an increased excess deaths in the future (Hatvani-Kovats et al., 2016). In order to avoid excess death during heat events in summer periods, the process of heat adaptation needs to follow the process of human activity and urbanization. Through improving the framework for urban plans and strategies for heat adaptation and proper public health intervention, a significant number of excess deaths could be avoidable. Some exact measures were proposed in Savić et al. (2018) research. Development of Heat Health Warning System for the Novi Sad could provide alert for heat events, and initiate emergency public health intervention, in order to prevent excess death. Understanding of natural hazard fatalities in geographical space is essential for developing effective disaster management programs and policies. Mapping where natural hazards have devastated impact across space and time can help in the selection of mitigation techniques, and delivery of capacity building and information dissemination (Aksha et al., 2017; Savić et al., 2018).

Reducing excess death is an important public health issue, particularly concerning the years of life lost (YLL). Recent analyses show that the relationship between extreme temperatures and the years of life lost for cardiovascular mortality has been U-shaped, with the increased years of life lost with both cold and hot temperatures and with significantly added effects of heat waves (Huang, Barnet, Wang, \& Tong, 2012). Still, future research needs to track impact on diverse latitudes and for other causes of death and the obtained heat-related mortality outputs could provide useful information for local authorities (emergency service, police, fire service), medical institutions, urban planners, building companies and ancillary services (Savić et al., 2018) that are in charge of creation strategies and directives in order to prevent population vulnerability.

\section{Conclusion}

The study confirmed significant relation between mortality and heat wave in urban population of Novi Sad, due to all cause and cardiorespiratory mortality. These results fit in context of recent research in Central Europe, improving, that old population (65 and over) as well population with cardiovascular and respiratory diseases are in high-risk group due to heat events.

The strengths of this study are a small mortality data used for the analysis and Ta measurement data from
25 stations in Novi Sad's urban area. Furthermore, an analysis relying on such a small sample makes it impossible to mitigate the random behaviour of mortality data and cover the missing counts. However, the NSUNET system, with one of the highest spatiotemporal frequencies of $\mathrm{T}_{\mathrm{a}}$ monitoring in urban areas in Central and Southeast Europe, helped capture urban climate processes and heat-related mortality more efficiently. The main advantage of the temperature da- 
tabase was that it did not rely on the standard monitoring from meteorological stations outside the city, but measurements were taken at stations located in different built-up areas in the urban area of Novi Sad. Therefore, it provided precise temperature signals that affected population living and working inside the urban area.

Some of the limitation of this paper should be pointed out. The main limitation in this research was the restricted period; therefore, the excess death could not be calculated. Socio-economic (e.g. education, occupation, income, housing, etc.) and some demographic characteristics (e.g. gender, marriage, etc.) recognized as risk factors that determine vulnerability to both hot and cold weather were also excluded from the analysis. This study has confirmed a high magnitude of association between mortality and temperature, and its results support research results from studies conducted in other cities in Europe, demonstrating that population in urban areas is highly vulnerable during heat wave periods. The results related to mortality trends under high temperature and during hot periods in summer are important for health risk assessments under climate change. As far as climate projections are concerned, the results of this study can contribute to future public health intervention thorught mitigation strategies and policies of heat-related mortality in Central Europe.

The main benefit of this study will be reflected not only in public health in Novi Sad and Serbian cities but also in other cities in Central Europe. The benefit of the presented methodology and results is that it can be applied in urban areas with different climates and topography, as well as sizes, levels of development and population densities.

\section{Acknowledgement}

This research has been partly contributed by the Ministry of Education, Science and Technological Development of the Republic of Serbia through the Project No. 176020. Authors are grateful for kind support (due to processing big databases) from dr Milovan Suvakov, Institute of Physics Belgrade.

\section{References}

Analitis, A., Katsouyanni, K., Biggeri, A., Baccini, M., Forsberg, B., Bisanti, L., Kirchmayer, U., Ballester, F., Cadum, E., goodman, PG., Hojs, a., Sunyer, J., Tittanen, P., \& Michelozzi, P. (2008). Effects of cold weather on mortality: results from 15 European cities within the PHEWE project. American Journal of Epidemiology, 168(12), 1397-1408. doi: 10.1093/aje/ kwn266

Aksha K.S., Juran K., Resler M.L. (2017). Spatial and temporal analysis of natural hazard mortality in Nepal. Environmental Hazards. doi.org/10.1080/174 77891.2017.1398630.

Arsenović D. (2019). Climate and population in Central Europe: results for temperature-related mortality in Novi Sad. In New Generations in Demography: New Challenging Adventures in the Population Sciene (Eds. Fisher J., Mazouch P., Hulikova Tesarkova K., Kurtinova O.), 27-35. Univeristy of Economics, Faculty of Informatics and Statistics, Prague. Oeconomica Publishing House. ISBN 978-80-245-2302-6

Arsenović, D., Lehnert, M., Fiedor, D., Šimáček, P., Středová, H., Středa, T., \& Savić, S. (2019). Heatwaves and Mortality in Czech Cities: A Case Study for the Summers of 2015 and 2016. Geographica Pannonica, 23(3), 162-172.
Arsenović D. (2018). Seasonality in human mortality: results for the City of Novi Sad (Serbia). Stanovništvo, 56(1). 27-42. doi.org/10.2298/ STNV1801027A

Arsenović, D., \& Đurđev, B. (2012). Karakteristike i izazovi starenja stanovništva Novog Sada. Zbornik radova Departmana za geografiju, turizam $i$ hotelijerstvo, 41, 84-93. [Features and challenges of population ageing in Novi Sad].

Baccini, M., Biggeri, A., Accetta, G., Kosatsky, T., Katsouyanni, K., Analitis, A., Anderson, H.R., Bisanti, L., D’Ippoliti, D., Danova, J., Forsberg, B., Medina, S., Paldy, A., Rabczenko, D., Schindler, C., \& Michelozzi, P. (2008). Heat effects on mortality in 15 European Cities. Epidemiology, 19(5), 711-719. doi: 10.1097/EDE.obo13e318176bfcd

Barriopedro, D., Fischer, E.M., Luterbacher, J., Trigo, M.R., \& Garcia-Herrera, R. (2011). The hot summer of 2010: redrawing the temperature record map of Europe. Science, 332(6026), 220-224. DOI: 10.1126/ science.1201224

Basu, R., \& Samet, J.M. (2002). Relation between Elevated Ambient Temperature and Mortality: A Review of the Epidemiologic Evidence. Epidemiologic Reviews, 24(2), 190-202. doi.org/10.1093/epirev/ mxfoo7 
Basu, R., Dominici, F., \& Samet, M.J. (2005). Temperature and mortality among the elderly in the United States: a comparation of epidemiologic methods. Epidemiology, 16(1), 58-66. DOI: 10.1097/01. ede.00o0147117.88386.fe

Black, E., Blackburn, M., Harrison, G., Hoskins, B., \& Methven, J. (2004). Factors contributing to the summer 2003 European heatwave. Weather, 59(8), 217-223. doi.org/10.1256/wea.74.04

Bobb, F.J., Peng, D.R., Bell, L.M., \& Dominici, F. (2014). Heat-related mortality and adaptation to heat in the United States. Environmental Research, 122(8), 811-816. doi: 10.1289/ehp.1307392

Bogdanović, D.C., Milošević, Z.G., Lazarević, K.K., Dolićanin, Z.C., Randelović, D.M., \& Bogdanović, S.D. (2013). The impact of the July 2007 heat wave on daily mortality in Belgrade, Serbia. Central European Journal of Public Health, 21(3), 140-145. DOI: 10.21101/cejph.a3840

Bustinza, R., Lebel, G., Gosselin, P., Belanger, D., \& Chebana, F. (2013). Health impact of the July 2010 heat wave in Quebec, Canada. BMC Public Health, 13:56.

Cheng, X., \& Su, H. (2010). Effects of climatic temperature stress on cardiovascular diseases. European Journal of Internal Medicine, 21(3), 164-167. doi. org/10.1016/j.ejim.2010.03.001

Conti, S., Meli, P., Minelli, G., Solimini, R., Toccaceli, V., Beltrano, C., \& Perini, L. (2005). Epidemiologic study of mortality during the summer 2003 heat wave in Italy. Environmental Research, 98, 390-399. doi.org/10.1016/j.envres.2004.10.009

Diaz, J., Garcia, R., Velazquez de Castro, F., Hernandez, E., Lopez, C., \& Otero, A. (2002). Effects of extremely hot days on people older than 65 years in Seville (Spain) from 1986 to 1997. International Journal of Biometeorology, 46, 145-149. doi.org/10.1007/ s00484-002-0129-Z

Djurdjev, B., Arsenović, D., \& Savić, S. (2012). Temperature-related mortality in Belgrade in the period 1888-2008. Acta Geographica Slovenica, 52-2, 385-401. doi.org/10.3986/AGS52205

Donaldson, G.C., Keatinge, W.R., \& Nayha, S. (2003). Changes in summer temperature and heat-related mortality since 1971 in North Carolina, South Finland, and Southest England. Environmental Research, 91, 1-7. doi.org/10.1016/Soo13-9351(02)0ooo2-6

Dong, B., Sutton, R., Shaffrey, L., \& Wilcox, L. (2016). The 2015 European Heat Wave. Bulletin of the American Meteorological Society, 97(12), S57-S62. DOI:10. II75/BAMS-d-I6-0140-I

Dousset, B., Laaidi, K., \& Zeghnoun, A. (2011). Surface temperature and mortality impact in the Paris region during August 2003 heat wave. Urban Climate News, 42:7-14.
Fouillet, A., Rey, G., Laurent, F., Pavillon, G., Bellec S., Guihenneuc-Jouyaux C., Clavel J., Jougla, E., \& Hemon D. (2006). Excess mortality related to the August 2003 heat wave in France. International Archives of Occupational and Environmental Health, 80(1),16-24. doi.org/10.1007/s00420-006-0089-4

Gabriel, M.A.K., \& Endlicher, R.W. (2011). Urban and rural mortality rates during heat waves in Berlin and Brandenburg, Germany. Environmental Pollution, 159, 2044-2050. DOI:10.1016/j.envpol.2011.01.016

Gasparrini, A., Guo, Y., Hashizume, M., Lavigne, E., Zanobetti, A., Schwartz, J., tobias, A., Tong, S., Rocklov, J., Forsberg, B., Leone, M., De Sario, M., Bell, Ml., Guo, YL., Wu, CF., Kan, H., Yi, SM., De Sousa Zanotti Stagliorio Cohelho, M., Saldiva, PH., Honda, Y., Kim, H., \& Armstrong, B. (2015). Mortality risk attribute to high and low ambient temperature: a multicountry observational study. Lancet, 386(9991), 369-375. DOI:10.1016/So1406736(14)62114-0

Goldberg, S.M., Gasparrini, A., Armstrong, B., \& Valois, M.F. (2011). The short-term influence of temperature on daily mortality in the temperate climate of Montreal, Canada. Environmental Research, 111, 853-86o. doi.org/10.1016/j.envres.2011.05.022

Hatvani-Kovacs, G., Belusko, M., Pockett, J., Boland, J. (2016). Assessment of Heatwave Impacts. Procedia Engineering, 169, 316-323. doi.org/10.1016/j.proeng.2016.10.039

Hoy, A., Hansel, S., Skalak, P., Ustrnul, Z., \& Bochniček O. (2017). The extreme European summer of 2015 in a long-term perspective. International Journal of Climatology, 37(2), 943-962. doi.org/10.1002/joc. 4751

Huang, C., Barnet, G.A., Wang, X., \& Tong, S. (2012). Effects of extrime temperatures on years of life lost for cardiovascular death: A time series study in Brisbane, Australia. Circulation: Cardiovascular Quaility and Outcomes, 5(5), 609-614. doi. org/10.1161/CIRCOUTCOMES.112.965707

Huth, R., Kysely, J., \& Pokorna, L. (2000). A GCM simulation of heat waves, dry spells, and their relationship to circulation. Climatic Change, 46, 29-60. doi. org/10.1023/A\%3A1005633925903

Hutter, H.P., Moshammer, H., Wallner, P., Leitner, B., $\&$ Kundi M. (2007). Heatwaves in Vienna: effects on mortality. Wiener Klinische Wochenschrift, 119(7-8), 223-227. doi.org/10.1007/s00508-006-0742-7

International Panel for Climate Change. Climate Change (2013). The Physical Science Basis. In: Stocker TF, Qin D, Plattern GK, Tignor M, Allen SK, Boschung J, Nauels A, Xia Y, Bex V, Midgley PM (eds.). Contribution of Working Group I of the Fifth Assessment Report of the Intergovernmental Panel on Climate Change. United Kingdom and 
New York, NY, USA, Cambridge University Press, Cambridge.

Jedlovec G., Crane D., \& Quattrochi D. (2017). Urban heat wave hazard and risk assessment. Results in Physics, 7, 4294-4295. doi.org/10.1016/j. rinp.2017.10.056

Kalkstein, L.S. (1993). Health and climate change: direct impact in cities. Lancet, 342(8884), 1397-1399. doi.org/10.1016/0140-6736(93)92757-k

Keller C.R. (2015). Fatal isolation: The devastating Paris heat wave of 2003. Chicago: The University of Chicago Press.

Kinney, P.L., O'Neill, M.S., Bell, M.L., \& Schwartz J. (2008). Approaches for estimating effects of climate change on heat-related deaths: challenges and opportunities. Environmental Science and Policy, 11(1), 87-96. doi.org/10.1016/j.envsci.2007.08.001

Klinenberg E. (2015). Heat wave: A social autopsy of disaster in Chicago. Second edition. Chicago: The University of Chicago Press.

Koppe, C., Kovats, S., Jendritzky, G., Menne, B., Baumüller, J., Bitan, A., Diaz Jiménez, J., Ebi, L.K., Havenith, G., Lopez Santiago, C., Michelozzi, P., Nicol, F., Matzarakis, A., McGregor, G., Nogueira J.P., Sheridan, S., \& Wolf, T. (2004). Heat-waves: risk and responses. Health and Global Environmental Change Series, no. 2, World Health Organization, Copenhagen, pp 123.

Kottek, M., Grieser, J., Beck, C., Rudolf, B., \& Rubel, F. (2006). World Map of the Koppen-Geiger climate classification updated. Meteorologische Zeitschrift, 15(3), 259-263.

Kovats, R.S., \& Kristie, L.E. (2006). Heatwaves and public health in Europe. European Journal of Public Health, 16(6), 592-599. DOI:10.1093/eurpub/cklo49

Kysely, J. (2002). Temporal fluctuations in heat waves at Prague-Klementinum, the Czech Republic, from 1901-1997, and their relationship to atmospheric circulation. International Journal of Climatology, 22, 33-50. DOI: 10.1002/joc.720

Kysely, J. (2004). Mortality and displaced mortality during heat waves in the Czech Republic. International Journal of Biometeorology, 49(2), 91-97. doi. org/10.1007/soo484-004-0218-2

Lehnert, M., Kubeček, J., Geletič, J., Jurek, M., \& Frajer, J. (2018). Identifying hot and cool spots in the city centre based on bicycle measurements: the case of Olomouc, Czech Republic. Geographica Pannonica, 22(4), 230-240.

Le Tertre, A., Lefranc, A., Eilstein, D., Declercq, C., Medina, S., Blanchard M., Chardon, B., Fabre, P., Filleul, L., Jusot, JF., Pascal, L., Prouvost, H., Cassadou, S., \& Ledrans, M. (2006). Impact of 2003 heat wave on all cause mortality in 9 French cit- ies. Epidemiology, 17(1), 75-79. DOI:10.1097/01. ede.0000187650.36636.1f

Lhotka, O., Kysely, J., \& Farda, A. (2017). Climate change scenarios of heat waves in Central Europe and their uncertainties. Theoretical and Applied Climatology, DOI 10.1007/so0704-016-2031-3.

Lubczynska, J.M., Christophi, A.C., \& Lelieveld, J. (2015). Heat-related cardiovascular mortality in Cyprus: a case-crossover study a distributed lag nonlinear model. Environmental Health, 2015, 14:39. DOI 10.1186/s12940-015-0025-8

Marti-Soler, H., Gonseth, S., Gubelmann, C., Stringhini, S., Bovet, P., Chen, P.C., Wojtyniak, B., Paccaud, F., Tsai, DH., Zdrojevski, T., \& MarquesVidal, P. (2014). Seasonal variation of overall and cardiovascular mortality: a study in 19 countries from different geographical locations. Plos One, 9(11), e11350o. doi.org/10.1371/journal.pone.0113500

Matzarakis, A., De Rocco, M., \& Najjar, G. (2009). Thermal bioclimate in Strasbourg-the 2003 heat wave. Theoretical and Applied Climatology, 98(3-4), 209-220. DOI:10.1007/s00704-009-0102-4

Matzarakis, A., Muthers, S., \& Koch, E. (2011). Human biometeorological evaluation of heat-related mortality in Vienna. Theoretical and Applied Climatology, 105(1), 1-10. DOI:10.1007/s00704-010-0372-x

McMichael, J.A., Woodruff, E.R., \& Hales S. (2006). Climate change and human health: present and future risks. Lancet, 367(9513), 859-869. DOI:10.1016/ So140-6736(06)68079-3

McMichael, J.A., Wilkinson, P., Kovats, S., Pattenden, S., Hajat, S., Armstrng B., Vajanapoom, N., Niciu, EM., Mahomed, H., Kingkeow, C., Kosnik, M., O'Neill, MS., romieu, I., Ramirez-Aguilar, M., Barreto, ML., Gouveia, N., \& Nikiforov, B. (2008). International study of temperature, heat and urban mortality: the ISOTHURM project. International Journal of Epidemiology, 37(5), 1121-1131. doi: 10.1093/ije/dyno86

Medina-Ramon, M., \& Schwartz, J. (2007). Temperature, temperature extremes, and mortality: a study of acclimatisation and effect modification in 50 US cities. Occupational and Environmental Medicine, 64 (12), 827-833. DOI:10.1136/oem.2007.033175

Meehl A.G., \& Tebaldi C. (2004). More intense, more frequent, and longer lasting heat waves in $21^{\text {st }}$ century. Science, 305 (5686), 994-997. DOI: 10.1126/science.1098704

Michelozzi, P., De Sairo, M., Accetta, G., De'Donato, F., Kirchmayer, U., D’Ovidio, M., \& Perucci, AC. (2006). Temperature and summer mortality: geographical and temporal variations in four Italian cities. Journal of Epidemiology and Community Health, 6o(5), 417-423. DOI:10.1136/jech.2005.040857 
Miron, J.I., Linares, C., Montero, C.J., Criado-Alvarez, J.J., \& Diaz J. (2015). Changes in cause-specific mortality during heat waves in central Spain, 1975-2008. International Journal of Biometeorology, 59(9), 12131222. DOI:10.1007/soo484-014-0933-2

Muthers, S., Matzarakis, A., \& Koch, E. (2010). Climate change and mortality in Vienna-A human biometeorological analysis based on regional climate modeling. International Journal of Environmental Research and Public Health, 7(7), 2965-2977. doi. org/10.3390\%2Fijerph7072965

Ongoma, V., Muange, K. P., \& Zablon, W. S. (2016). Potential effects of urbanization on urban thermal comfort, a case study of Nairobi city, Kenya: A review. Geographica Pannonica, 20(1), 19-31.

Pattenden, S., Nikiforov, B., \& Armstrong, B.G. (2003). Mortality and temperature in Sofia and London. Journal of Epidemiology and Community Health, 57(8), 628-633. doi.org/10.1136/jech.57.8.628

Russo, S., Sillmann, J., \& Ficher, M.E. (2015). Top ten European heatwaves since 1950 and their occurence in the coming decades. Environmental Research Letter, doi:10.1088/1748-9326/10/12/124003.

Savić, S., Milošević, D., Lazić, L., Marković, V., Arsenović, D., \& Pavić D. (2013). Classifying urban meteorological stations sites by "Local Climate Zones": Preliminary results for the City of Novi Sad (Serbia). Geographica Pannonica, 17(3), 60-68.

Savić, S., Milošević, D., Arsenović, D., Marković V., Bajšanski I., \& Šećerov I. (2016). Urban climate issues in complex urbanized environment review of the literature for Novi Sad (Serbia). Acta climatologica et chorologica, 49-50, 63-80.

Savić, S., Marković, V., Šećerov, I., Pavić, D., Arsenović, D., Milošević, D., Dolinaj, D., Nagy, I., \& Pantelić, M. (2018). Heat wave risk assessment and mapping in urban areas: case study for a midsized Central European city, Novi Sad (Serbia). Natural Hazards, doi:10.1007/s11069-017-3160-4.
Schwartz, J. (2005). Who is sensitive to extremes of temperature? A case-only analysis. Epidemiology, 16(1), 67-72. DOI: 10.1097/o1.ede.00oo147114.25957.71

Stanojević, G., Stojilković, J., Spalević, A., Kokotović, V. (2014). The impact of heat waves on daily mortality in Belgrade (Serbia) during summer. Environ Hazards-UK, 13(4), 392-342. doi.org/10.1080/1747789 1.2014 .932268

Stott, P.A., Stone, D.A., \& Allen, M.R. (2004). Human contribution to the European heatwave of 2003. $\mathrm{Na}$ ture, 432(7017), 610-614. DOI:10.1038/nature03089

Sun, Z. (2010). Cardiovascular to cold exposure. Frontiers in Bioscience, 2, 495-503.

Šećerov, I., Savić, S., Milošević, D., Marković, V., \& Bajšanski, I. (2015). Development of an automated urban climate monitoring system in Novi Sad (Serbia). Geographica Pannonica, 19, 174-183.

Stewart, I.D., Oke, T.R. (2012). Local climate zones for urban temperature studies. Bulletin of American Meteorological Society, 93, 1879-1900. http s:// doi.org/10.1175/BAMS -D-11-0001 9.1

Tong, S., Wang, Y.X., Yu, W., Chen, D., \& Wang, X. (2014). The impact of heatwaves on mortality in Australia: a multicity study. BMJ Open, 4:eoo3579. doi.org/10.1136/bmjopen-2013-003579

Wolf, K., Schneider, A., Breitner, S., Von Klot, S., Meisinger, C., Cyrys, J., Hymer, H., Wichmann HE., Peters, A., Peters, A., \& Cooperative Health Research in the Region of Augsburg Study Group. (2009). Air temperature and the occurance of myocardial infraction in Augsburg, Germany. Circulation, 120 (9), 735-742. DOI:10.1161/CIRCULATIONAHA.108.815860

Yi W., \& Chan, P.C.A. (2015). Effects of temperature on mortality in Hong Kong: a time series analysis. International Journal of Biometeorology, 59(7), 927936. DOI:10.1007/s00484-014-0895-4 